\title{
A Review of Enrofloxacin for Veterinary Use
}

\author{
Tessa Trouchon, Sébastien Lefebvre \\ USC 1233 INRA-Vetagro Sup, Veterinary School of Lyon, Marcy l'Etoile, France \\ Email: sebastien.lefebvre@vetagro-sup.fr
}

Received 12 January 2016; accepted 21 February 2016; published 26 February 2016

Copyright (C) 2016 by authors and Scientific Research Publishing Inc.

This work is licensed under the Creative Commons Attribution International License (CC BY). http://creativecommons.org/licenses/by/4.0/

(c) (i) Open Access

\begin{abstract}
This review outlines the current knowledge on the use of enrofloxacin in veterinary medicine from biochemical mechanisms to the use in the field conditions and even resistance and ecotoxicity. The basics of biochemistry, the mechanisms of action and resistance and pharmacokinetics are presented. Then an overview of available veterinary products, their efficacy and their toxicity against target species, human and environment is provided.
\end{abstract}

\section{Keywords}

Enrofloxacin, Antibiotic Resistances, Veterinary

\section{Introduction}

Enrofloxacin (Figure 1(c)), or 1-Cyclopropyl-6-fluoro-7-(4-ethyl-1-piperazinyl)-1,4-dihydro-4-oxo-3-quinolinecarboxylic acid, belongs to fluoroquinolone family which is a subfamily of quinolone. The first quinolone is the Nalidixic acid (Figure 1(a)) used in animal at the beginning of 1980s, enrofloxacin is the first fluoroquinolone patented in 1984 [1]. The huge evolution in the quinolone family is the addition of a fluor atom on the $6^{\text {th }}$ position which improves quinolones' antibacterial spectrum [2] and creates the fluoroquinolone subfamily. Quinolones have an action on bacterial topoisomerase. The marketing authorization reports a large antimicrobial spectrum for enrofloxacin, which is efficient on most gram-negative and gram-positive bacteria but not efficient on anaerobic bacteria [3]. But with 3.6 tons sold per year in France for animal use [4], fluroroquinolones are an important family in veterinary medicine that increases the probability of selecting resisting bacteria.

\section{Action Mechanism of Enrofloxacin}

\subsection{Important Physicochemical Properties of Enrofloxacin}

Enrofloxacin is a zwitterionic molecule with a $\mathrm{pKa}_{1}=[5.88-6.06]$ and a $\mathrm{pKa}_{2}=[7.70-7.74]$ [5]. The lowest 
<smiles>CCn1cc(C(=O)O)c(=O)c2ccc(C)nc21</smiles><smiles>O=C(O)c1cn(C2CC2)c2cc(N3CCNCC3)c(F)cc2c1=O</smiles>

(a)

(b)<smiles>CCN1CCN(c2cc3c(cc2F)c(=O)c(C(=O)O)cn3C2CC2)CC1</smiles>

(c)

Figure 1. Structure of (a) Nalidixic Acid; (b) Ciprofloxacin and (c) Enrofloxacin.

pKa is due to the carboxyl acid group and the second to the basic tertiary amine. So enrofloxacin doesn't bear charge between this two $\mathrm{pH}$. Moreover it is a lipophilic molecule with a logP of 4.70 at a pH of 7 [6], but $1.88 \pm$ 1.43 with ACDLabs.

The Active metabolite of enrofloxacin, ciprofloxacin (Figure 1(b)) or 1-Cyclopropyl-6-fluoro-1, 4-dihydro-7(1-piperazinyl)-4-oxo-3-quinoline carboxylic acid, which is available as a drug product on veterinary and human market, is a multiple acid with $\mathrm{pKa}_{1}=5.15$ and $\mathrm{pKa}_{2}=8.25$ [7]. Ciprofloxacin is less lipophilic than enrofloxacin with a $\log \mathrm{P}$ of -1.11 at a $\mathrm{pH}$ of 7.4 [8].

\subsection{Targets' Mechanism of Action}

Enrofloxacin, like the other quinolones, has two mains targets of the topoisomerase family. Although these proteins exist in eukaryotes cells, quinolones have less affinity for eukaryotes' topoisomerases than for the DNA Topoisomerase II (Gyrase) and the DNA Topoisomerase IV (Topo IV) two major bacterial topoisomerase [9]. The Gyrase and the Topo IV are two tetramers (Figure 2(a)) formed respectively of two GyrA and two GyrB and of two ParC and two ParE. Moreover GyrA and GyrB are homologous respectively with ParC and ParE [10].

The Gyrase has an important role in bacteria's life by modifying the topology of the spiral DNA. Indeed, the positive supercoiling stabilizes the DNA and the strands' separation becomes more difficult [11]. Moreover transcription generates a positive supercoiling accumulation that can stop transcription. This positive supercoiling can be released by the Gyrase, which enhances transcription [12]. To do this, the Gyrase binds and wraps around itself a strand of DNA (Figure 2(b)) with the help of the C-terminal domain [13] and cleaves it (Figure 2(c)) with mediating of the catalytic tyrosine Tyr 122 [14] of each GyrA. Tyrosines form covalent phosphotyrosyls with each 5' phosphoryl terminus of both strands, which remain binding during the reaction [15]. This reaction forms a gap in sequence (called G-DNA). The GyrB part catches the other DNA sequence (called transported DNA or T-DNA). The T-DNA is passed through the opened G-DNA (Figure 2(d)) [16]. The G-DNA is closed in an ATP-dependent reaction (Figure 2(e)) [17]. Of this reaction results an adding of negative coiling.

The Gyrase is able to do an intermolecular strand passage at the end of the replication like the Topo IV but 


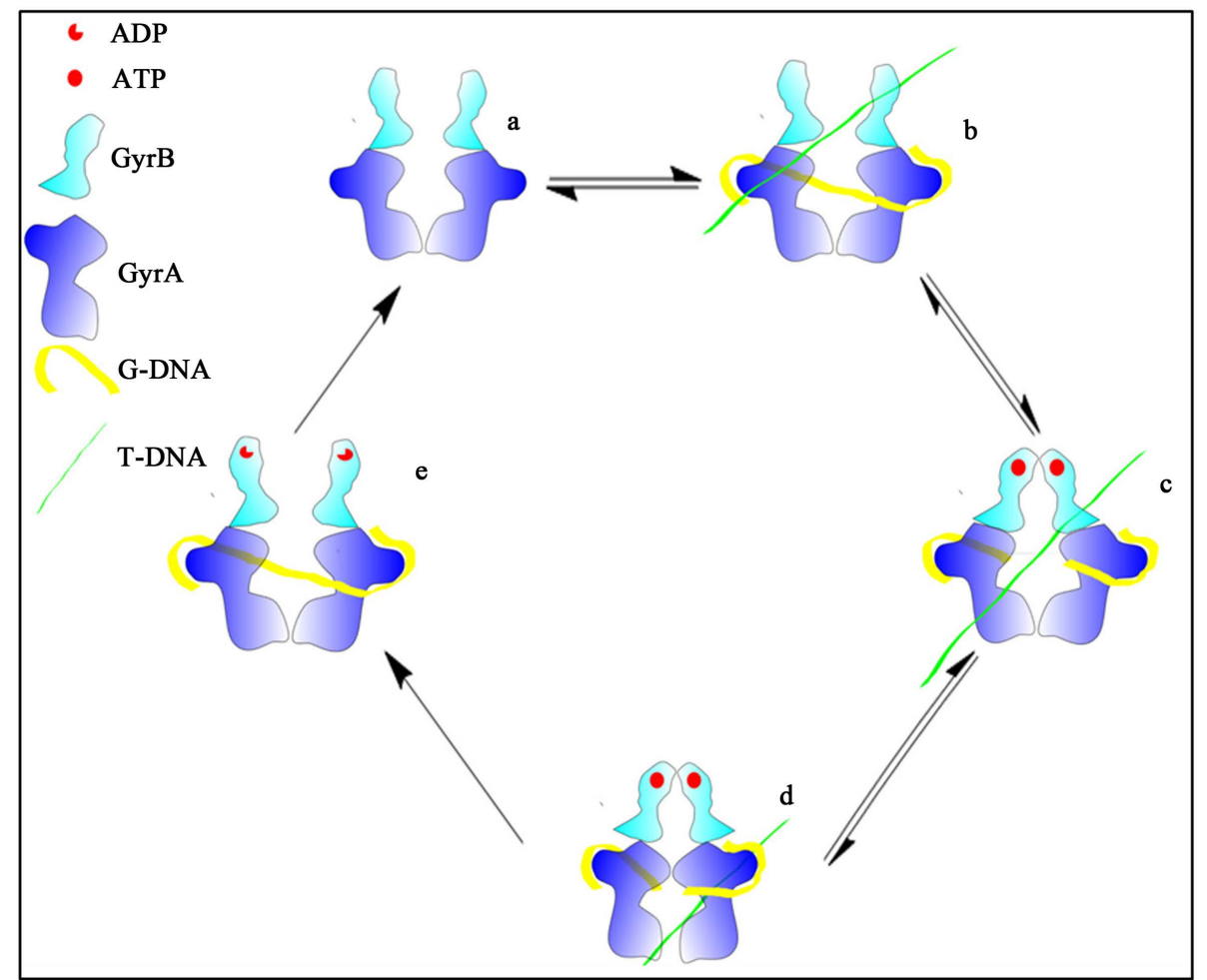

Figure 2. Mechanism of action of Gyrase, with intervention of Gyrase part A (GyrA) and B (GyrB), gap DNA sequence (G-DNA), transported DNA sequence (T-DNA), ATP and GDP. (a) Gyrase with GyrA dimer and GyrB dimer; (b) Interaction of Gyrase with two DNA sequences; (c) Fixation of an ATP molecule and cleavage of the G-DNA strand; (d) Passage of the T-DNA strand through G-DNA; (e) Closing of the G-DNA strand with ATP degradation.

without wrapping the DNA as the Topo IV, this is the major difference between reactions of both enzymes [18]. Topo IV catalyzes the segregation of the two daughter DNA molecules after the replication [19] more efficiently than Gyrase [20].

\subsection{Interactions between Fluoroquinolones, DNA and Its Target}

The penetration in the bacteria differs between Gram-positives and Gram-negatives bacteria. For Gram-negative bacteria, fluoroquinolones pass the outer membrane mainly through porins [21] [22]. The trimeric OmpF porin is mainly used by fluoroquinolone, this pathway can be modulated by $\mathrm{Mg}^{2+}$ [23]. But it seems that some quinolones can promote a pathway by interacting with the Lipopolysaccharide (LPS) and create a lipophilic passage [24]. For Gram-positive bacteria the diffusion process is the main uptake pathway [25].

In the case of mycobacteria the high lipid level of the membrane allows fluoroquinolones to diffuse through membrane [26].

After the entrance in the bacteria, quinolones have two effects on the bacteria: bacteriostatic at low concentration level or bactericide at high concentration level. Rapidly after the Gyrase has formed a complex with the DNA strand, two quinolones bind with this complex, before the DNA's cleavage [27]. This binding is reversible and induces a conformation modification in Gyrase [28]. This modification induces a cleavage of DNA in a particular location and forms a cleaved complex [29] [30]. At this step the action is still reversible, but reduces rapidly the activity of replication and has a bacteriostatic effect [31].

The next two pathways are possible one for bacteriostatic concentration and the other for bactericide concentration. For bacteriostatic concentrations, quinolones induce the SOS regulon controlled by the repressor lexA [32] [33]. Activation of the regulon induces the sfiA gene which codes for an inhibitor of cell division and bacteria form a long filamentous structure. This effect is still reversible [34]. This filamentous structure contributes to the death of bacteria [35]. 
For bactericide concentration quinolones induce a chromosome fragmentation by creation of a suicide factor or by destabilization of a GyrA dimer [35]. The fragmentation can induce a rapid death or, by reassociation of the GyrA dimer, genomic mutation in bacteria [36].

\subsection{Resistance Mechanism}

The resistance to fluoroquinolones in general, is today a main subject for the use of antibiotic substances in veterinary medicine and was the subject of an EMA report [4]. Many studies show an augmentation in the development of resistances to enrofloxacin [37] [38]. Moreover, another study shows the increase of resistance of Escherichia coli to quinolones and fluoroquinolones after using of enrofloxacin in calves [39].

The mechanism of resistance to fluoroquinolones is based on many pathways: the change of targets, the protection of target, the lower expression of target, the improvement of the efflux pumps, and inactivation of fluoroquinolones. These mechanisms can be chromosomal or plasmide-mediated (Table 1) [40].

The most common mechanism is the mutation of Gyrase. In the subpart GyrA the mutation is mainly between Ala67 and Gln 106 for E.coli and other bacteria [41] [42]. The mutation is near the GyrA active site which is called Quinolone Resistance-Determining Region (QRDR). For GyrB two mutation are reported at Asp426 and Lys447 [43]. Only one Gyrase mutation is able to increase the Minimum Inhibitory Concentration (MIC) up to 64 times [41], but the GyrB mutation seems to be less effective in resistance against nalidixic acid than the GyrA mutation [44].

The mutation of Topo IV is also described but, until today, always with at least one Gyrase mutation. Therefore, these mutations seem to be developed in a second time to increase the resistance more than only Gyrase's mutations. A QRDR can be also characterized in the parC of topoisomerase IV between Tyr 57 and Glu84 [45].

The protection of target can be attributed to a qnr gene often present on a Plasmide-Mediated Quinolone Resistance (PMQR) or in the chromosomal DNA. The Qnr protein is a dimere which binds with Gyrase and decreases the binding of quinolones with DNA-Gyrase-Qnr complex. But it seems that the Qnr protein reduces the interaction between DNA and Gyrase [46]. Another theory is that the Qnr protein destabilizes the DNA-Gyrasequinolone complex and promotes the DNA repair after cleavage [47].

An hypothesis of resistance is the slow growth of cell, bacteria growing slowly seem to resist better, but this mechanism is not known today [40] [48].

Although resistances are often attributed to the Gyrase or Topo IV mutations, decrease of influx and increase of efflux mechanisms are important pathways of resistance common to a large number of unrelated antibiotics [49]. This defines a Multiple Antimicrobial Resistance (MAR) phenotype. E. coli bearing a MAR operon has higher resistance for the quick death by fluoroquinolones [50]. This operon can induce a decrease of OmpF pumps [51] and an increase of efflux with AcrAB protein [52]. The decrease of porins can also be attributed to PMQR [53].

\subsection{Recommendations to Prevent Resistance}

Given the rapidity of development of resistance, we have to consider with the MIC, the Mutant Prevention Concentration (MPC). MPC is a recent indicator which is not well standardized. Commonly MPC50 is the concentration where $50 \%$ of the colonies doesn't contain resistant mutant after 72 hours of incubation. To count the mutants, a Polymerase Chain Reaction (PCR) is used but only known resistant mutation is tested [54]. Between MIC and MPC there is a window where enrofloxacin is effective but also where mutants are selected.

The data recorded in Table 2 show that the window between the MIC and the MPC can be very important with a MPC/MIC between 1.6 and 64. This high difference can explain the explosion of resistance against enrofloxacin and might be a base to define new guidelines and dosage for enrofloxacin.

Table 1. Possible origins of resistances to fluoroquinolones.

\begin{tabular}{cc}
\hline Chromosomal resistance & Plasmide-mediated resistance \\
\hline Mutation of target & Lower expression of target \\
Lower expression of target & Protection of target Improvement of efflux pumps \\
Protection of target Improvement of efflux pumps & Inactivation of fluoroquinolones \\
\hline
\end{tabular}


Table 2. MIC and MPC of enrofloxacin for some bacteria.

\begin{tabular}{|c|c|c|c|c|}
\hline Bacteria & MIC $(\mu \mathrm{g} / \mathrm{mL})$ & MPC $(\mu \mathrm{g} / \mathrm{mL})$ & (MPC/MIC) & References \\
\hline Escherichia coli & {$[0.022-0.03]$} & {$[0.17-0.5]$} & {$[7.8-16]$} & [67] [107] \\
\hline Staphylococcus pseudintermedius & 0.13 & 0.27 & 2 & [108] \\
\hline Rhodococcus equi & {$[0.5-1]$} & {$[8-64]$} & {$[16-64]$} & [109] \\
\hline Mannheimia haemolytica & 0.16 & 0.25 & 1.6 & [110] \\
\hline Salmonella Typhimurium & {$[0.06-0.125]$} & {$[1-2]$} & 16 & {$[67]$} \\
\hline Pseudomonas aeruginosa & 2 & {$[16-32]$} & {$[8-16]$} & [67] \\
\hline
\end{tabular}

\section{Pharmacokinetic of Enrofloxacin}

\subsection{Absorption}

There is high variation of bioavailability after oral administration of enrofloxacin between polygastric and monogastric animals from $10 \%$ to $80 \%$ [55] [56]. This has a direct consequences on the galenic, oral presentations are reserved for pigs, poultry, calves, and carnivores and only injectable solutions are available for cattle. Moreover, bioavailability depends on whether the animals are fed or fasted [55] [57], and of the presence of ion [58]. These interferences can be explained by the formation of a complex between cation and fluoroquinolone which cannot permeate through the digestive barrier [59]. Another consequence of this complex is the influence of the hardness of water notably in poultry farming where the dilution in water is used [60]. But lipophilic compounds in food can enhance oral bioavailability of fluoroquinolone [61].

In addition to passive diffusion allowed by enrofloxacin lipophilicity, active transporters have also an important role in intestinal absorption [62]. But these transporters are also important to eliminate fluoroquinolones [62].

The intramuscular bioavailability is $96 \%$ with a maximum concentration 3 hours after administration [3]. Intramuscular bioavailability can be enhanced by solid lipophilic nanoparticles, this technic enhances the duration of enrofloxacin in plasma [3].

\subsection{Metabolism}

After administration a high part of enrofloxacin is metabolized into ciprofloxacin in most of species (Table 3). Enrofloxacin has an active metabolite, ciprofloxacin [63], obtained by deethylation of the ethyl on the piperazin ring. Other metabolites are obtained but they don't have antimicrobial effects [64].

Only poultry does not have a huge part of enrofloxacin metabolized in ciprofloxacin. The first hepatic pass doesn't have a lot of effect, only 7\% of enrofloxacin is metabolized [65]. Moreover ciprofloxacin seems a more potent drug than enrofloxacin [66] [67]. These elements are in favor to grant a more important place to ciprofloxacin in the effects of enrofloxacin-based drugs.

\subsection{Distribution}

Distribution of enrofloxacin and ciprofloxacin to tissues depends on drug's free concentration, which depends itself on the concentration of protein and the strength of this biding.

The difference between ciprofloxacin and enrofloxacin protein binding (Table 4) are in favor of the theory of enrofloxacin's role of prodrug. Indeed, in some species ciprofloxacin is less bound with proteins, so it is able to be more available to be effective. Moreover, enrofloxacin can interact with other protein-binding drugs for instance it increases the clearance of flunixin meglubine [68].

As described in Table 5, the volumes of distribution of enrofloxacin and ciprofloxacin in different species are all higher than 1 . So enrofloxacin and its metabolite diffuse strongly in tissues, and molecules can be present in cells, so being inactive. Contrary to what we might expect considering its protein binding, ciprofloxacin doesn't diffuse in tissues more than enrofloxacin. Data of Table 6 suggest a high affinity of drugs for lung and kidney, even if data confirm enrofloxacin's and ciprofloxacin's good diffusion. 
Table 3. Percent of ciprofloxacin after enrofloxacin given.

\begin{tabular}{ccc}
\hline Species & Ciprofloxacin percent of enrofloxacin plasma concentration & References \\
\hline Dogs & 40 & {$[65]$} \\
Dairy cows & 59 & {$[75]$} \\
Steers & 64 & {$[75]$} \\
Chickens & $<10$ & {$[111]$} \\
Pigs & 51 & {$[112]$} \\
Goats & 34 & {$[71]$} \\
\hline
\end{tabular}

Table 4. Protein binding of enrofloxacin and ciprofloxacin.

\begin{tabular}{cccc}
\hline Species & Percent of bond enrofloxacin (\%) & Percent of bond ciprofloxacin (\%) & References \\
\hline Dogs & 34 & 18 & {$[113]$} \\
Dairy cows & 59.4 & 33.7 & {$[75]$} \\
Steers & 60.8 & 49.6 & {$[75]$} \\
Chickens & 23 & ND & {$[114]$} \\
Pigs & {$[31.1-37.1]$} & 35 & {$[115]$} \\
\hline
\end{tabular}

Table 5. Pharmacokinetics parameters of enrofloxacin and its metabolite ciprofloxacin.

\begin{tabular}{|c|c|c|c|c|c|c|c|}
\hline \multirow{2}{*}{ Species } & \multicolumn{2}{|c|}{$\mathbf{t}_{1 / 2}(\mathbf{h}) *$} & \multicolumn{2}{|c|}{$\mathrm{Cl}(\mathrm{mL} / \mathrm{min} / \mathrm{kg}) * *$} & \multicolumn{2}{|c|}{$\mathrm{V}_{\mathrm{ss}}(\mathrm{L} / \mathrm{kg}) * * *$} & \multirow{2}{*}{ References } \\
\hline & Enro & Cipro & Enro & Cipro & Enro & Cipro & \\
\hline Dogs & 2.3 & 2.8 & 12.16 & 7.8 & 2.45 & 1.92 & [65] \\
\hline Dairy cows & 3.69 & 2.96 & 24.16 & ND & 1.56 & ND & [75] \\
\hline Steers & 5.5 & 7.60 & 11.6 & ND & 1.59 & ND & [75] \\
\hline Chickens & 6.99 & 3.11 & 3.30 & 15.45 & 1.98 & 4.04 & {$[111]$} \\
\hline Pigs & 26.6 & 2.60 & 3.0 & 17.30 & 6.40 & 3.80 & [69] \\
\hline Goats & 1.39 & [1.82-2.72] & 22.18 & 19.59 & 1.27 & 3.33 & [71] [116] \\
\hline
\end{tabular}

* elimination half-live, ${ }^{* *}$ clearance, ${ }^{* * *}$ volume of distribution at the steady state. Enro: enrofloxacine, Cipro: ciprofloxacine.

Table 6. Maximal concentration (C) and area under the curve (AUC) of enrofloxacin (ENR) and ciprofloxacin (CIP) after an intravenous injection of $5 \mathrm{mg} / \mathrm{kg}$ of enrofloxacin [117].

\begin{tabular}{ccccccccccccccc}
\hline & \multicolumn{2}{c}{ Plasma $^{\dagger}$} & \multicolumn{2}{c}{ Muscle $^{\ddagger}$} & \multicolumn{2}{c}{ Liver $^{\ddagger}$} & \multicolumn{2}{c}{ Spleen $^{\ddagger}$} & \multicolumn{2}{c}{ Lung $^{\ddagger}$} & \multicolumn{2}{c}{ Kidney $^{\ddagger}$} \\
\hline & ENR & CIP & ENR & CIP & ENR & CIP & ENR & CIP & ENR & CIP & ENR & CIP \\
C & 4.44 & 0.18 & 3.48 & 0.19 & 3.67 & 2.95 & 11.04 & 0.25 & 3.82 & 0.86 & 8.98 & 2.78 \\
AUC & 3.52 & 0.61 & 5.61 & 0.62 & 5.76 & 2.02 & 10.44 & 2.08 & 9.44 & 4.79 & 9.03 & 4.91 \\
\hline
\end{tabular}

${ }^{\dagger} \mathrm{Unit}$ of $\mathrm{C}$ is $\mu \mathrm{g} / \mathrm{mL}$ and unit of AUC is $\mu \mathrm{g} . \mathrm{h} / \mathrm{mL}$; ${ }^{\ddagger}$ Unit of $\mathrm{C}$ is $\mu \mathrm{g} / \mathrm{g}$ and unit of AUC is $\mu \mathrm{g} . \mathrm{h} / \mathrm{g}$.

\subsection{Elimination}

Elimination parameters show great difference between species (Table 5), especially for pigs where the elimination half-life is high with $26 \mathrm{~h}$ [69]. Moreover, for chickens and pigs, clearance of ciprofloxacin is five times higher than enrofloxacin's clearance and their enrofloxacin clearances are lower than other species. This differences might be attributed to a difference of elimination way. 
Enrofloxacin's elimination way is mainly renal. This has been proved in rat by nephrecotomizing and comparing with $\mathrm{CCl}_{4}$ hepatic impairment [70] and in goat with probenecid [71]. Probenecid has been shown to reduce the renal clearance of fluoroquinolones [72]. On the other hand, ciprofloxacin's elimination is both hepatic and renal [73]. For both molecules there is an intestinal recirculation via the bile excretion, moreover, two hour after given, there is no significant difference in the concentration of enrofloxacin in the intestinal content between oral and intramuscular administration of enrofloxacin [74]. Lactation can influence significantly enrofloxacin's and ciprofloxacin's elimination by increasing two folds clearance in dairy cows comparative to steers [75]. It might be explained by an ionic trap.

\section{Veterinary Medicinal Products}

\subsection{Available Veterinary Medicines}

The first veterinary product based on enrofloxacin was launched by the laboratory Bayer in 1991 (marketing authorisation in 1991) under the trade name Baytril ${ }^{\circledR}$ and it was an oral form for poultry [3]. Now, many veterinary products on the basis of enrofloxacin are available on the market with at least thirty four veterinary medicines under different forms including oral and injectable forms, tablets or bolus [3]. There are many target species including domestic carnivores (dogs and cats), farm animals (cattle, pigs, poultry) and even exotic pets since 2010 [3].

\subsection{Therapeutic Indications and Uses in the Field Conditions}

Enrofloxacin is indicated in the treatment of local and systemic diseases caused by a wide range of Gram-negative and Gram-positive bacteria [4] [76]. The most important indication of enrofloxacin in all of the species is the treatment of respiratory infections but it is also indicated in the treatment of digestive, urinary, joint, genital, mammary and dermal infections [3] [77].

However, enrofloxacin is a third generation fluoroquinolone with a very large spectrum of activity so it has to be reserved to second intention. Indeed, in order to avoid fluoroquinolone resistances, it is important to reserve the use of enrofloxacin to infections resistant to over antibacterial agents and if possible under a susceptibility study [4].

In the field conditions, enrofloxacin is often off-label used empirically to prevent uterine infections in susceptible embryo-transfer mares. In fact, a conventional dose ( $5 \mathrm{mg} / \mathrm{kg}$ body weight) given pre-breeding followed by two further doses at 36 - 48 h post breeding are supposed to prevent bacterial adherence and provide effective bactericidal concentrations in utero [78].

Enrofloxacin is often used in aquaculture in Indonesia, Thailand and Vietnam. Indeed, because of the non-hygienic and stressful conditions in aquaculture facilities, the risk of bacterial infections is high and motivates the widely use of antibiotics in fish feed for prophylactic and therapeutic purpose [79].

\section{Therapeutic Efficacy}

Enrofloxacin is a powerful antimicrobial which have shown efficacy against a lot of bacterial diseases [4] [80]. The effectiveness of enrofloxacin against some bacterial infections in cattle, poultry, domestic carnivores (dogs and cats), rodents, lagomorphs and crustaceans has been assessed in many published studies, as well during natural infections as during experimental infections (Table 7). Among these studies, some relate to classical infections contained in the Summary of Product Characteristics (SPC) of veterinary products but some evaluate the efficacy of enrofloxacin in species for which there is no marketing authorisation or against specific bacteria such as Anaplasma marginale in cattle, Ehrlichia canis and Brucella canis in dogs, Bartonella henselae or Bartonella clarridgeiae and Chlamydophila felis in cats, Toxoplasma gondii in Calomys callosus or even Vibrio harveyi in Artemia franciscana (Table 7).

\section{Adverse Effects}

Overall, the fluoroquinolones are well tolerated with fewer adverse effects that are not very serious, especially when compared to their benefits [80] [81]. The most common side effects of enrofloxacin are digestive disorders including nausea, abdominal discomfort, vomiting and diarrhoea [81] [82] and inflammatory reaction at the site 
Table 7. Twenty published studies examining the efficacy of enrofloxacin.

\begin{tabular}{|c|c|c|c|c|c|c|c|}
\hline $\begin{array}{c}\text { Target } \\
\text { specie(s) }\end{array}$ & $\begin{array}{l}\text { Disease(s) and/or } \\
\text { bacterial agent(s) }\end{array}$ & $\begin{array}{l}\text { Type of } \\
\text { infection }\end{array}$ & $\begin{array}{l}\text { Regimen of } \\
\text { enrofloxacin }\end{array}$ & $\begin{array}{c}\text { Purpose } \\
\text { of the study }\end{array}$ & $\begin{array}{l}\text { Number } \\
\text { of animals }\end{array}$ & Result(s) & References \\
\hline \multicolumn{8}{|c|}{ CATTLE } \\
\hline $\begin{array}{l}\text { Dairy } \\
\text { cows }\end{array}$ & $\begin{array}{c}\text { Acute } \\
\text { clinical mastitis } \\
\text { (Escherichia coli) }\end{array}$ & $\mathrm{N}$ & $\begin{array}{l}5 \mathrm{mg} / \mathrm{kg} \text { IV } \\
\text { then SC } \\
24 \text { h later }\end{array}$ & $\begin{array}{c}\text { Comparative } \\
\text { efficacy of a ENR + } \\
\text { KET treatment and } \\
\text { a KET treatment }\end{array}$ & $\begin{array}{c}132 \\
\text { (64 ENR + KET, } \\
\text { no controls })\end{array}$ & $\begin{array}{l}\text { Inefficacy of } \\
\text { ENR to treat } \\
\text { acute clinical } \\
\text { E. coli mastitis }\end{array}$ & [118] \\
\hline $\begin{array}{l}\text { Sahiwal } \\
\text { cattle }\end{array}$ & $\begin{array}{l}\text { Anaplasma } \\
\text { marginale }\end{array}$ & $\mathrm{N}$ & $\begin{array}{c}5 \mathrm{mg} / \mathrm{kg} \text { IV } \\
\text { SID for } 5 \text { days }\end{array}$ & $\begin{array}{l}\text { Comparative } \\
\text { efficacy of ENR, } \\
\text { OXY and IMI }\end{array}$ & $\begin{array}{c}60 \\
\text { (15 per group } \\
+15 \text { controls) }\end{array}$ & $\begin{array}{l}\text { Inefficacy of } \\
\text { ENR to clear } \\
\text { persistent } \\
\text { infection }\end{array}$ & [119] \\
\hline $\begin{array}{l}\text { Holstein } \\
\text { calves }\end{array}$ & $\begin{array}{l}\text { Anaplasma } \\
\text { marginale }\end{array}$ & E & $\begin{array}{l}7.5 \mathrm{mg} / \mathrm{kg} \text { in a } \\
\text { single dose } \\
\text { or twice every } \\
3 \text { days }\end{array}$ & $\begin{array}{c}\text { Comparative } \\
\text { efficacy of ENR } \\
\text { (2 regimens) and } \\
\text { LA-OXY }\end{array}$ & $\begin{array}{c}24 \\
\text { (6 per group } \\
+6 \text { controls) }\end{array}$ & $\begin{array}{l}\text { Superiority } \\
\text { of ENR }\end{array}$ & [120] \\
\hline Calves & $\begin{array}{c}\text { Pneumonic } \\
\text { pasteurellosis } \\
\text { (Pasteurella } \\
\text { haemolytica A1) }\end{array}$ & $\mathrm{E}$ & $\begin{array}{l}2.5 \mathrm{mg} / \mathrm{kg} \mathrm{SC} \\
\text { SID for } 3 \text { days }\end{array}$ & Efficacy of ENR & $\begin{array}{c}36 \\
(12 \text { ENR }+12 \\
\text { positive controls } \\
+12 \text { negative } \\
\text { controls) }\end{array}$ & $\begin{array}{l}\text { Inefficacy } \\
\text { of ENR to treat } \\
\text { experimentally } \\
\text { induced } \\
\text { pneumonic } \\
\text { pasteurellosis }\end{array}$ & [121] \\
\hline $\begin{array}{l}\text { Feeder } \\
\text { calves }\end{array}$ & $\begin{array}{c}\text { Bovine } \\
\text { respiratory disease } \\
\text { (Mh, Pam, Hs, Mb) }\end{array}$ & $\mathrm{N}$ & $\begin{array}{c}12.5 \mathrm{mg} / \mathrm{kg} \\
\mathrm{SC} \text { in a } \\
\text { single injection }\end{array}$ & $\begin{array}{c}\text { Comparative } \\
\text { efficacy of ENR } \\
\text { and TUL in two } \\
\text { different } \\
\text { states of USA }\end{array}$ & $\begin{array}{c}500 \\
\text { (125 per } \\
\text { group per site) }\end{array}$ & $\begin{array}{l}\text { Superiority } \\
\text { of TUL }\end{array}$ & [122] \\
\hline \multicolumn{8}{|c|}{ POULTRY } \\
\hline Chickens & $\begin{array}{l}\text { Escherichia coli } \\
\text { (Ec) and } \\
\text { Pasteurella } \\
\text { multocida (Pam) }\end{array}$ & E & $\begin{array}{l}10 \mathrm{mg} / \mathrm{kg} \text { BID } \\
\text { in drinking water } \\
\text { for } 5 \text { days }\end{array}$ & $\begin{array}{l}\text { Efficacy of ENR } \\
\quad \text { (given } \\
\text { immediately } \\
\text { or } 6 \text { hours after } \\
\text { infection) }\end{array}$ & $\begin{array}{c}\text { Ec: } 30 \\
\text { (10 per group } \\
+10 \text { controls) } \\
\text { Pam: } 20 \\
\text { (7 per group } \\
+6 \text { controls) }\end{array}$ & $\begin{array}{c}\text { Efficacy } \\
\text { of ENR against } \\
\text { Ec and Pam }\end{array}$ & [123] \\
\hline Broilers & $\begin{array}{l}\text { Mycoplasma } \\
\text { gallisepticum } \\
\text { (Mg) }\end{array}$ & $\mathrm{N}$ & $\begin{array}{c}5 \mathrm{mg} / \mathrm{kg} \text { in } \\
\text { drinking water } \\
\text { at } 1-10 \text { and } \\
22-32 \text { days of } \\
\text { age }\end{array}$ & $\begin{array}{l}\text { Efficacy of ENR } \\
\text { in a treatment } \\
\text { program against } \\
\text { Mg in offspring of } \\
\text { Mg-infected } \\
\text { chicken-broiler } \\
\text { breeders }\end{array}$ & $\begin{array}{c}45,000 \\
(22,500 \text { ENR } \\
+ \\
22,500 \text { controls })\end{array}$ & $\begin{array}{l}\text { Efficacy } \\
\text { of ENR }\end{array}$ & [124] \\
\hline $\begin{array}{l}\text { Chicks } \\
\text { (White } \\
\text { Leghorn) }\end{array}$ & $\begin{array}{l}\text { Salmonella } \\
\text { enterica } \\
\text { Serovar } \\
\text { Typhimurium } \\
\text { DT104 }\end{array}$ & E & $\begin{array}{c}10 \mathrm{mg} / \mathrm{kg} \text { for } 5 \\
\text { days (1) or } 25 \\
\mathrm{mg} / \mathrm{kg} \text { for } 2 \text { days } \\
(2) \\
\text { or } 50 \mathrm{mg} / \mathrm{kg} \text { for } \\
1 \text { day (3) } \\
\text { (continuously } \\
\text { or pulsed in } \\
\text { water or gavage) }\end{array}$ & $\begin{array}{l}\text { Efficacy of ENR } \\
\text { (comparative } \\
\text { efficacy of high } \\
\text { dose short duration } \\
\text { treatments } \\
\text { and conventional } \\
\text { treatment) }\end{array}$ & $\begin{array}{l}481 \text { (151 in }(1) \\
+141 \text { in }(2) \\
+89 \text { in }(3) \\
+100 \text { controls })\end{array}$ & $\begin{array}{l}\text { Efficacy and } \\
\text { best compromise } \\
\text { for the 2-day } \\
2.5 \text { dosing } \\
\text { treatment }\end{array}$ & [125] \\
\hline $\begin{array}{l}\text { Broilers } \\
\text { (male } \\
\text { chicks) }\end{array}$ & $\begin{array}{c}\text { Colibacillosis } \\
\text { (Escherichia coli) }\end{array}$ & E & $\begin{array}{l}50 \mathrm{ppm} \text { in drink- } \\
\text { ing water for } 7 \\
\text { days }\end{array}$ & $\begin{array}{c}\text { Comparative } \\
\text { efficacy of } \\
\text { ENR and bacterio- } \\
\text { phage (individually } \\
\text { and in combination) }\end{array}$ & $\begin{array}{l}320 \text { ( } 40 \text { for } \\
\text { each one of the } \\
8 \text { treatments) }\end{array}$ & $\begin{array}{c}\text { Superiority of } \\
\text { ENR but synergy } \\
\text { between ENR } \\
\text { and bacteriophage }\end{array}$ & [126] \\
\hline $\begin{array}{l}\text { Turkeys } \\
\text { (poults) }\end{array}$ & $\begin{array}{c}\text { Respiratory } \\
\text { infections due to } \\
\text { Ornithobacterium } \\
\text { rhinotracheale } \\
\text { (associated with } \\
\text { avian } \\
\text { metapneumovirus) }\end{array}$ & E & $\begin{array}{l}10 \mathrm{mg} / \mathrm{kg} \text { in } \\
\text { drinking water } \\
\text { during } 20 \text { hours } \\
\text { for } 5 \text { days or } \\
50 \mathrm{mg} / \mathrm{kg} \text { during } \\
5,10 \text { or } 20 \text { hours } \\
\text { in a single day }\end{array}$ & $\begin{array}{l}\text { Efficacy of ENR } \\
\text { (comparative } \\
\text { efficacy of } \\
4 \text { regimens) }\end{array}$ & $\begin{array}{c}80 \text { (16 per } \\
\text { group }+ \\
16 \text { controls })\end{array}$ & $\begin{array}{c}\text { Superiority } \\
\text { of the } 10 \mathrm{mg} / \mathrm{kg} \\
\text { 5-day ENR } \\
\text { treatment }\end{array}$ & [127] \\
\hline
\end{tabular}




\section{Continued}

\section{DOMESTIC CARNIVORES}

\begin{tabular}{|c|c|c|c|c|c|c|}
\hline Dogs & $\begin{array}{c}\text { Ehrlichiosis } \\
\text { (Ehrlichia canis) }\end{array}$ & E & $\begin{array}{l}5 \text { or } 10 \mathrm{mg} / \mathrm{kg} \\
\text { PO BID } \\
\text { for } 21 \text { days }\end{array}$ & $\begin{array}{c}\text { Comparative } \\
\text { efficacy of ENR } \\
\text { (2 regimens) } \\
\text { and DOX }\end{array}$ & 13 & $\begin{array}{l}\text { Inefficacy of } \\
\text { ENR to clear } \\
\text { Ehrlichia } \\
\text { canis infection }\end{array}$ \\
\hline Dogs & $\begin{array}{c}\text { Recurrent } \\
\text { superficial (S) and } \\
\text { deep (D) } \\
\text { pyoderma }\end{array}$ & $\mathrm{N}$ & $\begin{array}{l}5 \mathrm{mg} / \mathrm{kg} \text { PO SID } \\
\text { continued up to } \\
1(\mathrm{~S}) \text { or } 2(\mathrm{D}) \\
\text { weeks after } \\
\text { clinical recovery }\end{array}$ & Efficacy of ENR & $9(\mathrm{~S})+3(\mathrm{D})$ & $\begin{array}{l}\text { Efficacy, } \\
\text { safety } \\
\text { and } \\
\text { convenience } \\
\text { of ENR }\end{array}$ \\
\hline Dogs & $\begin{array}{l}\text { Uncomplicated uri- } \\
\text { nary tract infections }\end{array}$ & $\mathrm{N}$ & $\begin{array}{c}18 \text { - } 20 \mathrm{mg} / \mathrm{kg} \\
\text { PO SID } \\
\text { for } 3 \text { days }\end{array}$ & $\begin{array}{l}\text { Comparative } \\
\text { efficacy of ENR } \\
\text { (high dose short } \\
\text { duration treatment) } \\
\text { and AMO-CLA }\end{array}$ & $\begin{array}{c}68 \text { (35 ENR + } 33 \\
\text { AMO-CLA) }\end{array}$ & $\begin{array}{l}\text { Non-inferiority } \\
\text { of a high dose } \\
\text { short duration } \\
\text { ENR treatment }\end{array}$ \\
\hline Dogs & $\begin{array}{c}\text { Brucellosis } \\
\text { (Brucella canis) }\end{array}$ & $\mathrm{N}$ & $\begin{array}{l}5 \mathrm{mg} / \mathrm{kg} \\
\text { PO BID } \\
\text { for } 30 \text { days }\end{array}$ & $\begin{array}{l}\text { Efficacy of ENR } \\
\text { for the eradication } \\
\text { of Brucella canis } \\
\text { in a kennel }\end{array}$ & 12 & $\begin{array}{l}\text { Incomplete } \\
\text { efficacy of ENR } \\
\text { but safety use } \\
\text { during gestation }\end{array}$ \\
\hline Cats & $\begin{array}{c}\text { Chronic } \\
\text { bartonellosis } \\
\text { (B. henselae and } \\
\text { B. clarridgeiae) }\end{array}$ & $\begin{array}{c}\mathrm{N} \\
(25 \text { cats }) \\
+\mathrm{E} \\
(18 \text { cats })\end{array}$ & $\begin{array}{c}22.7 \mathrm{mg} \\
\text { PO BID for } \\
14 \text { or } 28 \text { days }\end{array}$ & $\begin{array}{l}\text { Comparative efficacy } \\
\text { of ENR and DOX } \\
\text { (each one with } 2 \\
\text { treatment durations) }\end{array}$ & $\begin{array}{c}43 \\
(23 \mathrm{ENR}+ \\
17 \text { DOX + } \\
3 \text { controls) }\end{array}$ & $\begin{array}{l}\text { Efficacy of high } \\
\text { dose long duration } \\
\text { ENR treatment } \\
\text { (4 to } 6 \text { weeks) }\end{array}$ \\
\hline Cats & $\begin{array}{l}\text { Conjunctivitis } \\
\text { (Chlamydophila } \\
\text { felis) }\end{array}$ & $\mathrm{N}$ & $\begin{array}{c}5 \mathrm{mg} / \mathrm{kg} \text { SC SID } \\
\text { for } 3 \text { days then } \\
\text { PO SID for } \\
11 \text { days }\end{array}$ & $\begin{array}{l}\text { Comparative } \\
\text { efficacy of } \\
\text { ENR and DOX }\end{array}$ & $\begin{array}{c}25 \\
(14 \mathrm{ENR} \\
+11 \mathrm{DOX})\end{array}$ & $\begin{array}{c}\text { Equal } \\
\text { improvement } \\
\text { of ENR and } \\
\text { DOX } \\
\text { in clinical } \\
\text { signs } \\
\text { and infection } \\
\text { status }\end{array}$ \\
\hline \multicolumn{7}{|c|}{ RODENTS } \\
\hline Mice & $\begin{array}{c}\text { Systemic } \\
\text { infections } \\
\text { (Escherichia coli) }\end{array}$ & E & $\begin{array}{l}5 \mathrm{mg} / \mathrm{kg} \\
\mathrm{SC} \text { or PO }\end{array}$ & $\begin{array}{l}\text { Efficacy of ENR } \\
\text { (2 different routes } \\
\text { of administration) }\end{array}$ & NP & $\begin{array}{l}\text { Efficacy of ENR } \\
\text { and superiority } \\
\text { of the } \\
\text { injectable } \\
\text { form (SC) }\end{array}$ \\
\hline $\begin{array}{l}\text { lomys } \\
\text { llosus }\end{array}$ & $\begin{array}{l}\text { Toxoplasmosis } \\
\text { (Toxoplasma } \\
\text { gondii) }\end{array}$ & E & $\begin{array}{l}3 \mathrm{mg} / \mathrm{kg} \\
\text { SC SID for } \\
3 \text { days }\end{array}$ & $\begin{array}{l}\text { Comparative } \\
\text { efficacy of } \\
\text { ENR and SUL }\end{array}$ & $\begin{array}{c}15 \\
(5 \text { ENR }+5 \\
\text { SUL }+5 \text { controls })\end{array}$ & $\begin{array}{l}\text { Efficacy of ENR } \\
\text { as a potential } \\
\text { alternative drug }\end{array}$ \\
\hline
\end{tabular}

\section{LAGOMORPHS}

\begin{tabular}{|c|c|c|c|}
\hline Rabbits & $\begin{array}{c}\text { Pasteurella } \\
\text { multocida (Pam) }\end{array}$ & $\begin{array}{c}\text { N (11 rab- } \\
\text { bits) } \\
+\mathrm{E}(12 \\
\text { rabbits) }\end{array}$ & $\begin{array}{l}5 \mathrm{mg} / \mathrm{kg} \text { SC BID } \\
\quad \text { for } 10 \text { days }\end{array}$ \\
\hline
\end{tabular}

\section{CRUSTACEANS}

Artemia franciscana (nauplii)
Vibrio harveyi (strain PN9801)
ENR 4h before infection (A) or $24 \mathrm{~h}$ after infection (B)
Efficacy of ENR in the elimination of Pam from asymptomatically infected rabbits
Inefficacy

of ENR

$11(\mathrm{~N})+12(\mathrm{E}) \quad$ to eliminate

Pasteurella

multocida

\footnotetext{
Comparative

efficacy of

ENR (2 regimens)
}

Efficacy of

ENR

to stop the course of a bacterial infection in Artemia franciscana 
of injection for injectable forms, particularly in pigs [3]. However, some more serious adverse effects of enrofloxacin could appear targetting the juvenile joints, the reproductive system, the ocular system and the central nervous system.

The best known adverse effects of enrofloxacin concern the joints of young animals and result in arthropathy, articular cartilage degeneration, tendonitis and other forms of tendon injury [80] [81] [83] [84]. In order to try to understand quinolone related-arthropathy, a study was carried out in 1994 on juvenile New Zealand White Rabbits indicating that quinolones stimulate the cellular respiratory burst of immature articular chondrocytes which results in the production of oxygen-derived compounds highly toxic for the cartilage [83]. However the mechanisms underlying fluoroquinolones-induced tendinopathy and cartilage degeneration remained incompletely understood. Thus, further studies were necessary such as the study carried out in 2008 on canine Achilles tendon cells and chondrocytes suggesting that enrofloxacin-induced tendinopathy and cartilage damage could be explained by the inhibition of cell proliferation, induction of apoptosis and DNA fragmentation [84]. In young chickens, a study led in 2009 to determine the chondrotoxic effects of enrofloxacin on avian articular cartilage indicates that only very high dosage of enrofloxacin can induce toxic effects in articular cartilage of growing chickens and that the intensity of chondrotoxicity is dose- and time-dependent. Thus it is suggested that quinolone-induced arthropathy is far less expressed in birds than in mammals [85].

To assess the effects of enrofloxacin on adult joints, a study was carried out in 2000. The effects of long-term administration of an injectable enrofloxacin solution were evaluated by the monitoring of physical and musculoskeletal variables in adult horses. Adverse effects were only detected with high doses and consist of lameness, cellulitis, tendinitis, sheath effusion and even transient neurologic signs [86].

The adverse effects of enrofloxacin on the reproductive system were mainly investigated in males in order to assess the impact of this antibiotic on the fertility parameters. A study carried out in 2008 in male chickens suggested that enrofloxacin at therapeutical dose does not affect the sperm motility, the weight of testes, wattles and combs and the testicular concentration of testosterone, ascorbic acid, total protein and cholesterol [87]. On the opposite, a study led in the same year to evaluate toxic effects of enrofloxacin on sperm quality in male mice indicates that a fixed $150 \mathrm{mg} / \mathrm{kg}$ dose of enrofloxacin could lead to structural damages in the testicular tissue resulting in disruption of spermatogenesis in the testes with deterioration of motility, content and morphology of sperms [81]. Although the toxicity of enrofloxacin on the female reproductive tract was less investigated, a recent study on the use of intrauterine enrofloxacin infusion in healthy mares reveals acute effects including endometrial ulceration, necrosis and haemorrhage and chronic effects including fibrosis and inflammation [88].

The ocular toxicity of enrofloxacin has been suggested by the association of enrofloxacin, retinal degeneration and blindness in cats [89] [90]. A retrospective clinical study carried out to assess the possible connection between the administration of parenteral enrofloxacin and the onset of acute retinal degeneration in cats highlights the potential retinotoxicity of parenteral enrofloxacin which can result in acute and diffuse retinal degeneration, particularly with dosages exceeding $5 \mathrm{mg} / \mathrm{kg}$ once daily (which is the manufacturer's current dosage recommendation). Mydriasis and blindness were frequently observed but some cats may recover their sight [89].

At slightly higher doses, central nervous system signs of lethargy, anorexia and hypersalivation were observed in dogs as shown in a recent study carried out to assess a high dose short duration enrofloxacin protocol in dogs with uncomplicated urinary tract infections [82].

\section{Residues and Toxicity for Consumers}

In many animal species, the use of enrofloxacin lead to its de-ethylation to its primary metabolite ciprofloxacin and both enrofloxacin and ciprofloxacin would be found as drug residues in animal muscle and tissue [76] [91].

The consumption of meat containing these residues represent a significant threat against human health because it may result in disruption of the colonization barrier, development of drug-resistant bacterial strains or even allergies [91] [92]. In this regard, a recent study provides information on in vitro testing to determine if concentrations of veterinary antimicrobial agent residues entering the human colon remain microbiologically active [92]. Thus, the authorities have defined Acceptable Daily Intakes (ADI) of antimicrobial veterinary residues by human. The European Medicines Agency (EMA) have set the overall ADI value for enrofloxacin at 6.2 $\mu \mathrm{g} / \mathrm{kg}$ body weight [92] [93] corresponding to the microbiological ADI because it is lower than the toxicological ADI of $12 \mu \mathrm{g} / \mathrm{kg}$ body weight which was calculated by applying a safety factor of 100 to the No Observed Effect Level (NOEL) of $1.2 \mathrm{mg} / \mathrm{kg}$ body weight per day [94]. 
In order to protect consumer's health, many countries have defined Maximum Residue Limits (MRL) of enrofloxacin and ciprofloxacin in animal-derived products [76]. In the European Union (EU), the MRLs of enrofloxacin and ciprofloxacin in muscle tissues and milk of all species are $100 \mu \mathrm{g} / \mathrm{L}$ [93] but as there is no MRL for enrofloxacin in eggs, enrofloxacin is forbidden in animals form which eggs are produced for human consumption [93].

To measure the enrofloxacin and ciprofloxacin residues in animal-derived foods including milk, eggs, honey and even mane and tail hair in horses, many analytical methods have been developed. Among these methods, we can mention High Performance Liquid Chromatography (HPLC); HPLC-Diode Array Detection method combined with liquid chromatography-mass spectrometry; HPLC-Ultraviolet Diode Array Detection method; molecularly imprinted solid-phase extraction procedure; liquid chromatography using a metal chelate affinity column; finally, the method of ChemiLuminescence Enzyme ImmunoAssay [76] [77] [91] [95]-[97].

\section{Ecotoxicity}

The release of enrofloxacin and ciprofloxacin in the environment is mainly due to the direct discharge of aquaculture products and the excretion in urine and feces of livestock animals [98]. It results in the contamination of soil, surface water, sediment, ground water and biota [99]. Once released into the environment the behavior of a chemical substance is determined by its tendency to partition from the aqueous phase to the atmosphere which is expressed by the Henry's Law Constant (HLC) and its affinity to adsorb on solid which is expressed by the Octanol-Water Partition Constant (Kow or log Kow) [99]. Enrofloxacin have a very low HLC at ambient temperature $\left(<10-15 \mathrm{~atm} \cdot \mathrm{m}^{3} \cdot \mathrm{mol}^{-1}\right)$ resulting in a negligible volatile loss and its Kow is low (0.83) while enrofloxacin have a high affinity for sludge, soils and sediments [99].

In the environment, enrofloxacin and ciprofloxacin can undergo degradations by different processes including photolysis, biodegradation and oxidation by mineral oxides but they are not sensitive to hydrolysis [99]. Despite these degradation mechanisms, environmental half-life time of enrofloxacin and ciprofloxacin are very long (half-life time estimated between 1155 and 3466 days for ciprofloxacin in a mesocosm soil study performed by Walters et al. in 2010, indicating an important persistence in soil matrices [100].

This long environmental persistence of enrofloxacin and ciprofloxacin can affect the growing or the activity of the soil microbial communities [101]. Indeed, although some edaphic organisms may utilize and decompose enrofloxacin as a nutrient, it is suggested that enrofloxacin or ciprofloxacin concentrations exceeding $0.2 \mathrm{mg} / \mathrm{kg}$ result in significant toxicity for the edaphon [101] [102]. Thus, edaphic ammonification and nitrification are affected and the edaphon community structure is modified, which can impact the soil fertility [102]. Furthermore, a quite recent study carried out in 2008 indicates that the exposure of whole earthworms and their different tissues to various concentrations of enrofloxacin can lead to changes in catalase activity and to a lesser extent, in growth rate [103].

The toxicity of enrofloxacin and ciprofloxacin for aquatic ecosystems has been assessed in many studies, as well on microorganisms as on algae or even aquatic vertebrates and invertebrates [104] [105]. Among these studies, three were carried out recently in zebrafish embryos [106], in tropical freshwater ecosystems with the monitoring of macro-invertebrates, zooplankton, phytoplankton, periphyton, bacteria, organic matter decomposition and nitrogen cycling [105] and in three tropical aquatic species (the green-algae Chlorella sp., the micro-invertebrate Moina macrocopa and the Nile tilapia Oreochromis niloticus) collected in a stream receiving effluents from a Pangasius catfish farm which uses enrofloxacin [104]. The results of these three studies are similar, suggesting that residual concentrations of enrofloxacin and ciprofloxacin in aquatic environment are not likely to result in direct or indirect severe toxic effects on aquatic ecosystems [104]-[106].

\section{Conclusion}

The fluoroquinolones are one of the most useful classes of antibiotics, as well in human medicine as in veterinary medicine. Thanks to their broad spectrum of activity against a wide range of bacteria and their physicochemical properties, their use is increasing. Enrofloxacin, which is a third generation fluoroquinolone only available in veterinary medicine, is thus used in many species with few adverse effects. However, there are recent concerns about the emergence of quinolone-resistant bacterial strains and the impact on the environment of the overuse of these drugs. Thus, there is now an important need to use fluoroquinolones with caution to preserve their effectiveness for many years. In veterinary medicine, it is essential to reserve these drugs for cases 
requiring a powerful antibiotic and to prescribe and/or administer them only under a good clinical assessment and with appropriate regimens.

\section{Acknowledgements}

We thank Prs. Marc Le Borgne, Plamen Kirilov and Caroline Prouillac for helpful suggestions and comments and Virginie Durand for its proofreading.

\section{References}

[1] Grohe, K., Zeiler, H.-J., Metzger, K.G. and Grohe, K. (1987) 7-Amino-1-Cyclopropyl-4-Oxo-1, 4-Dihydro-Quinolineand Naphthyridine-3-Carboxylic Acids and Antibacterial Agents Containing These Compounds. US4670444 (A). http://worldwide.espacenet.com/publicationDetails/biblio?FT=D\&date=19870602\&DB=EPODOC\&locale=en_EP\&C $\mathrm{C}=\mathrm{US} \& N R=4670444 \mathrm{~A} \& \mathrm{KC}=\mathrm{A} \& \mathrm{ND}=5$

[2] Wright, D.H., Brown, G.H., Peterson, M.L. and Rotschafer, J.C. (2000) Application of Fluoroquinolone Pharmacodynamics. Journal of Antimicrobial Chemotherapy, 46, 669-683. http://dx.doi.org/10.1093/jac/46.5.669

[3] Fauchier, N. (2013) Med’Vet, le recueil des spécialités à usage vétérinaire. 2014th Edition, Med'com, Paris.

[4] Committee for Medicinal Products for Veterinary Use (CVMP) (2007) Public Statement on the Use of (Fluoro) Quinolones in Food-Producing Animals in the European Union: Development of Resistance and Impact on Human and Animal Health.

[5] Barbosa, J., Barrón, D., Jiménez-Lozano, E. and Sanz-Nebot, V. (2001) Comparison between Capillary Electrophoresis, Liquid Chromatography, Potentiometric and Spectrophotometric Techniques for Evaluation of $\mathrm{p} K_{\mathrm{a}}$ Values of Zwitterionic Drugs in Acetonitrile-Water Mixtures. Analytica Chimica Acta, 437, 309-321. http://dx.doi.org/10.1016/S0003-2670(01)00997-7

[6] Lizondo, M., Pons, M., Gallardo, M. and Estelrich, J. (1997) Physicochemical Properties of Enrofloxacin. Journal of Pharmaceutical and Biomedical Analysis, 15, 1845-1849. http://dx.doi.org/10.1016/S0731-7085(96)02033-X

[7] Lin, C.-E., Deng, Y.-J., Liao, W.-S., Sun, S.-W., Lin, W.-Y. and Chen, C.-C. (2004) Electrophoretic Behavior and pK Determination of Quinolones with a Piperazinyl Substituent by Capillary Zone Electrophoresis. Journal of Chromatography A, 1051, 283-290. http://dx.doi.org/10.1016/j.chroma.2004.08.069

[8] Takács-Novák, K., Józan, M., Hermecz, I. and Szász, G. (1992) Lipophilicity of Antibacterial Fluoroquinolones. International Journal of Pharmaceutics, 79, 89-96. http://dx.doi.org/10.1016/0378-5173(92)90099-N

[9] Levine, C., Hiasa, H. and Marians, K.J. (1998) DNA Gyrase and Topoisomerase IV: Biochemical Activities, Physiological Roles during Chromosome Replication, and Drug Sensitivities. Biochimica et Biophysica Acta (BBA)-Gene Structure and Expression, 1400, 29-43. http://dx.doi.org/10.1016/S0167-4781(98)00126-2

[10] Kato, J., Nishimura, Y., Imamura, R., Niki, H., Hiraga, S. and Suzuki, H. (1990) New Topoisomerase Essential for Chromosome Segregation in E. coli. Cell, 63, 393-404. http://dx.doi.org/10.1016/0092-8674(90)90172-B

[11] Anselmi, C., Bocchinfuso, G., De Santis, P. and Fuà, M. (1998) A. Scipioni, M. Savino, Statistical Thermodynamic Approach for Evaluating the Writhe Transformations in Circular DNAs. The Journal of Physical Chemistry B, 102, 5704-5714. http://dx.doi.org/10.1021/jp981552v

[12] Chong, S., Chen, C., Ge, H. and Xie, X.S. (2014) Mechanism of Transcriptional Bursting in Bacteria. Cell, 158, 314326. http://dx.doi.org/10.1016/j.cell.2014.05.038

[13] Gubaev, A. and Klostermeier, D. (2014) The Mechanism of Negative DNA Supercoiling: A Cascade of DNA-Induced Conformational Changes Prepares Gyrase for Strand Passage. DNA Repair, 16, 23-34.

http://dx.doi.org/10.1016/j.dnarep.2014.01.011

[14] Horowitz, D.S. and Wang, J.C. (1987) Mapping the Active Site Tyrosine of Escherichia coli DNA Gyrase. The Journal of Biological Chemistry, 262, 5339-5344.

[15] Tse, Y.C., Kirkegaard, K. and Wang, J.C. (1980) Covalent Bonds between Protein and DNA. Formation of Phosphotyrosine Linkage between Certain DNA Topoisomerases and DNA. The Journal of Biological Chemistry, 255, 55605565.

[16] Wang, J.C., (1998) Moving One DNA Double Helix through Another by a Type II DNA Topoisomerase: The Story of a Simple Molecular Machine. Quarterly Reviews of Biophysics, 31, 107-144. http://dx.doi.org/10.1017/S0033583598003424

[17] Gellert, M., Mizuuchi, K., O’Dea, M.H. and Nash, H.A. (1976) DNA Gyrase: An Enzyme that Introduces Superhelical Turns into DNA. Proceedings of the National Academy of Sciences of the United States of America, 73, 3872-3876. http://dx.doi.org/10.1073/pnas.73.11.3872 
[18] Peng, H. and Marians, K.J. (1995) The Interaction of Escherichia coli Topoisomerase IV with DNA. The Journal of Biological Chemistry, 270, 25286-25290. http://dx.doi.org/10.1074/jbc.270.42.25286

[19] Peng, H. and Marians, K.J. (1993) Decatenation Activity of Topoisomerase IV during oriC and pBR322 DNA Replication in Vitro. Proceedings of the National Academy of Sciences of the United States of America, 90, 8571-8575. http://dx.doi.org/10.1073/pnas.90.18.8571

[20] Zechiedrich, E.L. and Cozzarelli, N.R. (1995) Roles of Topoisomerase IV and DNA Gyrase in DNA Unlinking during Replication in Escherichia coli. Genes \& Development, 9, 2859-2869. http://dx.doi.org/10.1101/gad.9.22.2859

[21] Danilchanka, O., Pavlenok, M. and Niederweis, M. (2008) Role of Porins for Uptake of Antibiotics by Mycobacterium Smegmatis. Antimicrobial Agents and Chemotherapy, 52, 3127-3134. http://dx.doi.org/10.1128/AAC.00239-08

[22] Yamano, Y., Nishikawa, T. and Komatsu, Y. (1999) Outer Membrane Proteins Responsible for the Penetration of $\beta$-Lactams and Quinolones in Pseudomonas Aeruginosa. Journal of Antimicrobial Chemotherapy, 26, 175-184. http://dx.doi.org/10.1093/jac/26.2.175

[23] Brauser, A., Schroeder, I., Gutsmann, T., Cosentino, C. and Moroni, A., Hansen, U.-P., et al. (2012) Modulation of Enrofloxacin Binding in OmpF by $\mathrm{Mg}^{2+}$ as Revealed by the Analysis of Fast Flickering Single-Porin Current. The Journal of General Physiology, 140, 69-82. http://dx.doi.org/10.1085/jgp.201210776

[24] Bryan, L.E. and Bedard, J. (1991) Impermeability to Quinolones in Gram-Positive and Gram-Negative Bacteria. ropean Journal of Clinical Microbiology \& Infectious Diseases, 10, 232-239. http://dx.doi.org/10.1007/BF01966995

[25] Bedard, J., Wong, S. and Bryan, L.E. (1987) Accumulation of Enoxacin by Escherichia coli and Bacillus Subtilis. Antimicrobial Agents and Chemotherapy, 31, 1348-1354. http://dx.doi.org/10.1128/AAC.31.9.1348

[26] Lambert, P. A. (2002) Cellular Impermeability and Uptake of Biocides and Antibiotics in Gram-Positive Bacteria and Mycobacteria. Journal of Applied Microbiology, 92, 46S-54S. http://dx.doi.org/10.1046/j.1365-2672.92.5s1.7.x

[27] Kampranis, S.C. and Maxwell, A. (1998) The DNA Gyrase-Quinolone Complex ATP Hydrolysis and the Mechanism of DNA Cleavage. The Journal of Biological Chemistry, 273, 22615-22626. http://dx.doi.org/10.1074/jbc.273.35.22615

[28] Kampranis, S.C. and Maxwell, A. (1998) Conformational Changes in DNA Gyrase Revealed by Limited Proteolysis. The Journal of Biological Chemistry, 273, 22606-22614. http://dx.doi.org/10.1074/jbc.273.35.22606

[29] Leo, E., Gould, K.A., Pan, X.-S., Capranico, G., Sanderson, M.R., Palumbo, M., et al. (2005) Novel Symmetric and Asymmetric DNA Scission Determinants for Streptococcus Pneumoniae Topoisomerase IV and Gyrase Are Clustered at the DNA Breakage Site. The Journal of Biological Chemistry, 280, 14252-14263. http://dx.doi.org/10.1074/jbc.M500156200

[30] Lockshon, D. and Morris, D.R. (1985) Sites of Reaction of Escherichia coli DNA Gyrase on pBR322 in Vivo as Revealed by Oxolinic Acid-Induced Plasmid Linearization. Journal of Molecular Biology, 181, 63-74. http://dx.doi.org/10.1016/0022-2836(85)90324-9

[31] Wentzell, L.M. and Maxwell, A. (2000) The Complex of DNA Gyrase and Quinolone Drugs on DNA Forms a Barrier to the T7 DNA Polymerase Replication Complex. Journal of Molecular Biology, 304, 779-791. http://dx.doi.org/10.1006/jmbi.2000.4266

[32] Kelley W.L. (2006) Lex Marks the Spot: The Virulent Side of SOS and a Closer Look at the LexA Regulon. Molecular Microbiology, 62, 1228-1238. http://dx.doi.org/10.1111/j.1365-2958.2006.05444.x

[33] Malik, M., Zhao, X. and Drlica (2006) K., Lethal Fragmentation of Bacterial Chromosomes Mediated by DNA Gyrase and Quinolones. Molecular Microbiology, 61, 810-825. http://dx.doi.org/10.1111/j.1365-2958.2006.05275.x

[34] Maguin, E., Lutkenhaus, J. and D’Ari, R. (1986) Reversibility of SOS-Associated Division Inhibition in Escherichia coli. Journal of Bacteriology, 166, 733-738.

[35] Drlica, K., Malik, M., Kerns, R.J., Zhao, X. (2008) Quinolone-Mediated Bacterial Death, Antimicrob. Antimicrobial Agents and Chemotherapy. 52, 385-392. http://dx.doi.org/10.1128/AAC.01617-06

[36] Gocke, E. (1991) Mechanism of Quinolone Mutagenicity in Bacteria. Mutation Research/Fundamental and Molecular Mechanisms of Mutagenesis, 248, 135-143. http://dx.doi.org/10.1016/0027-5107(91)90095-6

[37] Cohn, L.A., Gary, A.T., Fales, W.H. and Madsen, R.W. (2003) Trends in Fluoroquinolone Resistance of Bacteria Isolated from Canine Urinary Tracts. Journal of Veterinary Diagnostic Investigation, 15, 338-343. http://dx.doi.org/10.1177/104063870301500406

[38] Cummings, K.J., Aprea, V.A. and Altier, C. (2014) Antimicrobial Resistance Trends among Escherichia coli Isolates Obtained from Dairy Cattle in the Northeastern United States, 2004-2011. Foodborne Pathogens and Disease, 11, 61-67. http://dx.doi.org/10.1089/fpd.2013.1605

[39] Pereira, R.V., Siler, J.D., Ng, J.C., Davis, M.A., Grohn, Y.T. and Warnick, L.D. (2014) Effect of On-Farm Use of Antimicrobial Drugs on Resistance in Fecal Escherichia coli of Preweaned Dairy Calves. Journal of Dairy Science, 41, 
92-99. http://dx.doi.org/10.3168/jds.2014-8521

[40] Ruiz, J., Pons, M.J. and Gomes, C. (2012) Transferable Mechanisms of Quinolone Resistance. International Journal of Antimicrobial Agents, 40, 196-203. http://dx.doi.org/10.1016/j.ijantimicag.2012.02.011

[41] Drlica, K. and Zhao, X. (1997) DNA Gyrase, Topoisomerase IV, and the 4-Quinolones. Microbiology and Molecular Biology Reviews, 61, 377-392.

[42] Yoshida, H., Bogaki, M., Nakamura, M. and Nakamura, S. (1990) Quinolone Resistance-Determining Region in the DNA Gyrase gyrA Gene of Escherichia coli. Antimicrobial Agents and Chemotherapy, 34, 1271-1272. http://dx.doi.org/10.1128/AAC.34.6.1271

[43] Yoshida, H., Bogaki, M., Nakamura, M., Yamanaka, L.M. and Nakamura, S. (1991) Quinolone Resistance-Determining region in the DNA Gyrase gyrA Gene of Escherichia coli. Antimicrobial Agents and Chemotherapy, 35, 1647-1650. http://dx.doi.org/10.1128/AAC.35.8.1647

[44] Nakamura, S., Nakamura, M., Kojima, T. and Yoshida, H. (1989) gyrA and gyrB Mutations in Quinolone-Resistant Strains of Escherichia coli. Antimicrobial Agents and Chemotherapy, 33, 254-255. http://dx.doi.org/10.1128/AAC.33.2.254

[45] Hopkins, K.L., Davies, R.H. and Threlfall, E.J. (2005) Mechanisms of Quinolone Resistance in Escherichia coli and Salmonella: Recent Developments. International Journal of Antimicrobial Agents, 25, 358-373. http://dx.doi.org/10.1016/j.ijantimicag.2005.02.006

[46] Tran, J.H., Jacoby, G.A. and Hooper, D.C. (2005) Interaction of the Plasmid-Encoded Quinolone Resistance Protein Qnr with Escherichia coli DNA Gyrase. Antimicrobial Agents and Chemotherapy, 49, 118-125. http://dx.doi.org/10.1128/AAC.49.1.118-125.2005

[47] Vetting, M.W., Hegde, S.S., Wang, M., Jacoby, G.A., Hooper, D.C. and Blanchard, J.S. (2011) Structure of QnrB1, a Plasmid-Mediated Fluoroquinolone Resistance Factor. The Journal of Biological Chemistry, 286, 25265-25273. http://dx.doi.org/10.1074/jbc.M111.226936

[48] Dalhoff, A., Matutat, S. and Ullmann, U. (1995) Effect of Quinolones against Slowly Growing Bacteria. Chemotherapy, 41, 92-99. http://dx.doi.org/10.1159/000239329

[49] George, A.M. and Levy, S.B. (1983) Amplifiable Resistance to Tetracycline, Chloramphenicol, and Other Antibiotics in Escherichia coli: Involvement of a Non-Plasmid-Determined Efflux of Tetracycline. Journal of Bacteriology, 155, 531-540.

[50] Goldman, J.D., White, D.G. and Levy, S.B. (1996) Multiple Antibiotic Resistance (Mar) Locus Protects Escherichia coli from Rapid Cell Killing by Fluoroquinolones. Antimicrobial Agents and Chemotherapy, 40, 1266-1269.

[51] Cohen, S.P., McMurry, L.M. and Levy, S.B. (1988) MarA Locus Causes Decreased Expression of OmpF Porin in Multiple-Antibiotic-Resistant (Mar) Mutants of Escherichia coli. Journal of Bacteriology, 170, 5416-5422.

[52] Tavío, M. del M., Vila, J., Ruiz, J., Ruiz, J., Martín-Sánchez, A.M. and de Anta, M.T.J. (1999) Mechanisms Involved in the Development of Resistance to Fluoroquinolones in Escherichia coli Isolates. Journal of Antimicrobial Chemotherapy, 44, 735-742. http://dx.doi.org/10.1093/jac/44.6.735

[53] Martínez-Martínez, L., Pascual, A. and Jacoby, G.A. (1998) Quinolone Resistance from a Transferable Plasmid. The Lancet, 351, 797-799. http://dx.doi.org/10.1016/S0140-6736(97)07322-4

[54] Blondeau, J.M., Zhao, X., Hansen, G. and Drlica, K. (2001) Mutant Prevention Concentrations of Fluoroquinolones for Clinical Isolates of Streptococcus Pneumoniae. Antimicrobial Agents and Chemotherapy, 45, 433-438. http://dx.doi.org/10.1128/AAC.45.2.433-438.2001

[55] Nielsen, P. and Gyrd-Hansen, N. (1997) Bioavailability of Enrofloxacin after Oral Administration to Fed and Fasted Pigs. Pharmacology \& Pharmaceutical Medicine, 80, 246-250. http://dx.doi.org/10.1111/j.1600-0773.1997.tb01967.x

[56] Vancutsem, P., Babish, J. and Schwark, W. (1990) The Fluoroquinolone Antimicrobials: Structure, Antimicrobial Activity, Pharmacokinetics, Clinical Use in Domestic Animals and Toxicity. The Cornell Veterinarian, 80, 173-186.

[57] Steinman, A., Britzi, M., Levi, O., Lavy, E., Lichter, A. and Soback, S. (2006) Lack of Effect of Diet on the Pharmacokinetics of Enrofloxacin in Horses. Journal of Veterinary Pharmacology and Therapeutics, 29, 67-70. http://dx.doi.org/10.1111/j.1365-2885.2006.00717.x

[58] Ziółkowski, H., Jaroszewski, J.J., Maślanka, T., Grabowski, T., Katolik, K., Pawęska, J., et al. (2014) Influence of Oral Co-Administration of a Preparation Containing Calcium and Magnesium and Food on Enrofloxacin Pharmacokinetics. Research in Veterinary Science, 97, 99-104. http://dx.doi.org/10.1016/j.rvsc.2014.05.005

[59] Simon, Ž., Katja, B., Darko, U., Marjan, V. and Albin, K. (2010) Metal Cation-Fluoroquinolone Complexes Do Not Permeate through the Intestinal Absorption Barrier. Journal of Pharmaceutical and Biomedical Analysis, 53, 655-659. http://dx.doi.org/10.1016/j.jpba.2010.05.021

[60] Sumano, L.H., Gutierrez, O.L., Aguilera, R., Rosiles, M.R., Bernard, B.M.J., Gracia, M.J. (2004) Influence of Hard 
Water on the Bioavailability of Enrofloxacin in Broilers. Poultry Science, 83, 726-731. http://dx.doi.org/10.1093/ps/83.5.726

[61] Coulet, M., Morello, C., Cox, P. and Lohuis, J. (2005) Pharmacokinetics of Ibafloxacin in Healthy Cats. Journal of Veterinary Pharmacology and Therapeutics, 28, 37-44. http://dx.doi.org/10.1111/j.1365-2885.2004.00623.x

[62] Dautrey, S., Felice, K., Petiet, A., Lacour, B., Carbon, C. and Farinotti, R. (1999) Active Intestinal Elimination of Ciprofloxacin in Rats: Modulation by Different Substrates, British Journal of Pharmacology, 127, 1728-1734. http://dx.doi.org/10.1038/sj.bjp.0702703

[63] Tyczkowska, K., Hedeen, K.M., Aucoin, D.P. and Aronson, A.L. (1989) High-Performance Liquid Chromatographic Method for the Simultaneous Determination of Enrofloxacin and Its Primary Metabolite Ciprofloxacin in Canine Serum and Prostatic Tissue. Journal of Chromatography B: Biomedical Sciences and Applications, 493, 337-346. http://dx.doi.org/10.1016/S0378-4347(00)82739-5

[64] Riviere, J.E., and Papich, M.G. (2013) Veterinary Pharmacology and Therapeutics. John Wiley \& Sons, Hoboken, 993.

[65] Cester, C.C. and Toutain, P.L. (1997) A Comprehensive Model for Enrofloxacin to Ciprofloxacin Transformation and Disposition in Dog. Journal of Pharmaceutical Sciences, 86, 1148-1155. http://dx.doi.org/10.1021/js9603461

[66] Küng, K., Riond, J.-L. and Wanner, M. (1993) Pharmacokinetics of Enrofloxacin and Its Metabolite Ciprofloxacin after Intravenous and Oral Administration of Enrofloxacin in Dogs. Journal of Veterinary Pharmacology and Therapeutics, 16, 462-468. http://dx.doi.org/10.1111/j.1365-2885.1993.tb00212.x

[67] Pasquali, F. and Manfreda, G. (2007) Mutant Prevention Concentration of Ciprofloxacin and Enrofloxacin against Escherichia coli, Salmonella Typhimurium and Pseudomonas Aeruginosa. Veterinary Microbiology, 119, 304-310. http://dx.doi.org/10.1016/j.vetmic.2006.08.018

[68] Ogino, T., Mizuno, Y., Ogata, T. and Takahashi, Y. (2005) Pharmacokinetic Interactions of Flunixin Meglumine and Enrofloxacin in Dogs. American Journal of Veterinary Research, 66, 1209-1213. http://dx.doi.org/10.2460/ajvr.2005.66.1209

[69] Nouws, J.F.M., Mevius, D.J., Vree, T.B., Baars, A.M. amd Laurensen, J. (1988) Pharmacokinetics, Renal Clearance and Metabolism of Ciprofloxacin Following Intravenous and Oral Administration to Calves and Pigs. Veterinary Quarterly, 10, 156-163. http://dx.doi.org/10.1080/01652176.1988.9694165

[70] Hwang, Y.H., Kim, M.S., Song, I.B., Lim, J.H., Park, B.K. and Yun, H.I. (2009) Altered Pharmacokinetics of Enrofloxacin in Experimental Models of Hepatic and Renal Impairment. Veterinary Research Communications, 33, 481-487. http://dx.doi.org/10.1007/s11259-008-9195-y

[71] Rao, G.S., Ramesh, S., Ahmad, A.H., Tripathi, H.C., Sharma, L.D. and Malik, J.K. (2002) Pharmacokinetics of Enrofloxacin and Its Metabolite Ciprofloxacin in Goats Given Enrofloxacin Alone and in Combination with Probenecid. The Veterinary Journal, 163, 85-93. http://dx.doi.org/10.1053/tvjl.2001.0594

[72] Neuman, M. (1986) Comparative Pharmacokinetic Parameters of New Systemic Fluoroquinolones. International Journal of Clinical Pharmacology Research, 7, 173-179.

[73] Martinez, M., McDermott, P. and Walker, R. (2006) Pharmacology of the Fluoroquinolones: A Perspective for the Use in Domestic Animals. The Veterinary Journal, 172, 10-28. http://dx.doi.org/10.1016/j.tvjl.2005.07.010

[74] Wiuff, C., Lykkesfeldt, J., Aarestrup, F.M. and Svendsen, O. (2002) Distribution of Enrofloxacin in Intestinal Tissue and Contents of Healthy Pigs after Oral and Intramuscular Administrations. Journal of Veterinary Pharmacology and Therapeutics, 25, 335-342. http://dx.doi.org/10.1046/j.1365-2885.2002.00430.x

[75] Idowu, O.R., Peggins, J.O., Cullison, R. and von Bredow, J. (2010) Comparative Pharmacokinetics of Enrofloxacin and Ciprofloxacin in Lactating Dairy Cows and Beef Steers Following Intravenous Administration of Enrofloxacin. Research in Veterinary Science, 89, 230-235. http://dx.doi.org/10.1016/j.rvsc.2009.12.019

[76] Yu, F., Yu, S., Yu, L., Li, Y., Wu, Y., Zhang, H., et al. (2014) Determination of Residual Enrofloxacin in Food Samples by a Sensitive Method of Chemiluminescence Enzyme Immunoassay. Food Chemistry, 149, 71-75. http://dx.doi.org/10.1016/j.foodchem.2013.10.024

[77] Cinquina, A.L., Roberti, P., Giannetti, L., Longo, F., Draisci, R., Fagiolo, A., et al. (2003) Determination of Enrofloxacin and Its Metabolite Ciprofloxacin in Goat Milk by High-Performance Liquid Chromatography with Diode-Array Detection: Optimization and Validation. Journal of Chromatography A, 987, 221-226. http://dx.doi.org/10.1016/S0021-9673(02)01800-9

[78] González, C., Moreno, L., Fumuso, E., García, J., Rivulgo, M., Confalonieri, A., et al. (2009) Enrofloxacin-Based Therapeutic Strategy for the Prevention of Endometritis in Susceptible Mares. Journal of Veterinary Pharmacology and Therapeutics, 33, 287-294. http://dx.doi.org/10.1111/j.1365-2885.2009.01135.x

[79] Sapkota, A., Sapkota, A.R., Kucharski, M., Burke, J., McKenzie, S., Walker, P., et al. (2008) Aquaculture Practices and Potential Human Health Risks: Current Knowledge and Future Priorities. Environment International, 34, 12151226. http://dx.doi.org/10.1016/j.envint.2008.04.009 
[80] Sarkozy, G. (2001) Quinolones: A Class of Antimicrobial Agents. Veterinární Medicína (Praha), 46, 257-274.

[81] Aral, F., Karaçal, F. and Baba, F. (2008) The Effect of Enrofloxacin on Sperm Quality in Male Mice. Research in Veterinary Science, 84, 95-99. http://dx.doi.org/10.1016/j.rvsc.2007.04.007

[82] Westropp, J.L., Sykes, J.E., Irom, S., Daniels, J.B., Smith, A., Keil, D., et al. (2012) Evaluation of the Efficacy and Safety of High Dose Short Duration Enrofloxacin Treatment Regimen for Uncomplicated Urinary Tract Infections in Dogs. Journal of Veterinary Internal Medicine, 26, 506-512. http://dx.doi.org/10.1111/j.1939-1676.2012.00914.X

[83] Hayem, G., Petit, P.X., Levacher, M., Gaudin, C., Kahn, M.F. and Pocidalo, J.J. (1994) Cytofluorometric Analysis of Chondrotoxicity of Fluoroquinolone Antimicrobial Agents. Antimicrobial Agents and Chemotherapy, 38, $243-247$. http://dx.doi.org/10.1128/AAC.38.2.243

[84] Lim, S., Hossain, M.A., Park, J., Choi, S.H. and Kim, G. (2008) The Effects of Enrofloxacin on Canine Tendon Cells and Chondrocytes Proliferation in Vitro. Veterinary Research Communications, 32, 243-253. http://dx.doi.org/10.1007/s11259-007-9024-8

[85] Maślanka, T., Jaroszewski, J.J., Mikołajczyk, A. and Rotkiewicz, T. (2009) Effect of Increasing Doses of Enrofloxacin on Chicken Articular Cartilage. Polish Journal of Veterinary Sciences, 12, 21-33.

[86] Bertone, A.L., Tremaine, W.H., Macoris, D.G., Simmons, E.J., Ewert, K.M., Herr, L.G., et al. (2000) Effect of Long-Term Administration of an Injectable Enrofloxacin Solution on Physical and Musculoskeletal Variables in Adult Horses. Journal of the American Veterinary Medical Association, 217, 1514-1521. http://dx.doi.org/10.2460/javma.2000.217.1514

[87] Al-Nazawi, M.H. (2008) Effects of Enrofloxacin and Marbofloxacin Administration on Some Fertility Parameters of Male Chicken. Journal of Taibah University for Science, 1, 1-4. http://dx.doi.org/10.1016/S1658-3655(12)60027-2

[88] Rodriguez, J.S., Han, S., Nielsen, S., Pearson, L.K., Gay, J.M. and Tibary, A. (2012) Consequences of Intrauterine Enrofloxacin Infusion on Mare Endometrium. Journal of Equine Veterinary Science, 32, 106-111. http://dx.doi.org/10.1016/j.jevs.2011.08.003

[89] Gelatt, K.N., Van Der Woerdt, A., Ketring, K.L., Andrew, S.E., Brooks, D.E., Biros, D.J., et al. (2001) Enrofloxacin-Associated Retinal Degeneration in Cats. Veterinary Ophthalmology, 4, 99-106. http://dx.doi.org/10.1046/j.1463-5224.2001.00182.x

[90] Giuliano, E.A. and van der Woerdt, A. (1999) Feline Retinal Degeneration: Clinical Experience and New Findings (1994-1997). Jaaha-American Animal Hospital Association, 35, 511-514. http://dx.doi.org/10.5326/15473317-35-6-511

[91] Yan, H., Tian, M. and Row, K.H. (2008) Determination of Enrofloxacin and Ciprofloxacin in Milk Using Molecularly Imprinted Solid-Phase Extraction. Journal of Separation Science, 31, 3015-3020. http://dx.doi.org/10.1002/jssc.200800315

[92] Ahn, Y., Linder, S.W., Veach, B.T., Steve Yan, S., Haydée Fernández, A., Pineiro, S.A., et al. (2012) In Vitro Enrofloxacin Binding in Human Fecal Slurries. Regulatory Toxicology and Pharmacology, 62, 74-84. http://dx.doi.org/10.1016/j.yrtph.2011.11.013

[93] Committee for Medicinal Products for Veterinary Use (CVMP) (2002) Enrofloxacin, Summary Report (5).

[94] Committee for Medicinal Products for Veterinary Use (CVMP) (1998) Enrofloxacin, Summary Report (2).

[95] Dunnett, M., Richardson, D.W. and Lees, P. (2004) Detection of Enrofloxacin and Its Metabolite Ciprofloxacin in Equine Hair. Research in Veterinary Science, 77, 143-151. http://dx.doi.org/10.1016/j.rvsc.2004.03.004

[96] Gorla, N., Chiostri, E., Ugnia, L., Weyers, A., Giacomelli, N., Davicino, R., et al. (1997) HPLC Residues of Enrofloxacin and Ciprofloxacin in Eggs of Laying Hens. International Journal of Antimicrobial Agents, 8, 253-256. http://dx.doi.org/10.1016/S0924-8579(97)00018-6

[97] Yatsukawa, Y., Ito, H., Matsuda, T., Nakamura, M., Watai, M. and Fujita, K. (2011) Determination of Residual Fluoroquinolones in Honey by Liquid Chromatography Using Metal Chelate Affinity Chromatography. Journal of AOAC International, 94, 1319-1327.

[98] Boxall, A., Kolpin, D., Holling-Sorensen, B. and Tolls, J. (2003) Are Veterinary Medicines Causing Environmental Risks? Environmental Science \& Technology, 15, 286A-294A.

[99] Van Doorslaer, X., Dewulf, J., Van Langenhove, H. and Demeestere, K. (2014) Fluoroquinolone Antibiotics: An Emerging Class of Environmental Micropollutants. Science of the Total Environment, 500-501, 250-269. http://dx.doi.org/10.1016/j.scitotenv.2014.08.075

[100] Walters, E., McClellan, K. and Halden, R.U. (2010) Occurrence and Loss Over Three Years of 72 Pharmaceuticals and Personal Care Products from Biosolids-Soil Mixtures in Outdoor Mesocosms. Water Research, 44, 6011-6020. http://dx.doi.org/10.1016/j.watres.2010.07.051

[101] Girardi, C., Greve, J., Lamshöft, M., Fetzer, I., Miltner, A., Schäffer, A., et al. (2011) Biodegradation of Ciprofloxacin 
in Water and Soil and Its Effects on the Microbial Communities. Journal of Hazardous Materials, 198, 22-30. http://dx.doi.org/10.1016/j.jhazmat.2011.10.004

[102] Zhou, X., Chen, C., Yue, L., Sun, Y., Ding, H. and Liu, Y. (2008) Excretion of Enrofloxacin in Pigs and Its Effect on Ecological Environment. Environmental Toxicology and Pharmacology, 26, 272-277. http://dx.doi.org/10.1016/j.etap.2008.04.004

[103] Gao, Y., Sun, X., Sun, Z., Zhao, N. and Li, Y. (2008) Toxic Effects of Enrofloxacin on Growth Rate and Catalase Activity in Eisenia fetida. Environmental Toxicology and Pharmacology, 26, 177-180. http://dx.doi.org/10.1016/j.etap.2008.03.004

[104] Andrieu, M., Rico, A., Phu, T.M., Huong, D.T.T., Phuong, N.T. and Van den Brink, P.J. (2015) Ecological Risk Assessment of the Antibiotic Enrofloxacin Applied to Pangasius Catfish Farms in the Mekong Delta, Vietnam. Chemosphere, 119, 407-414. http://dx.doi.org/10.1016/j.chemosphere.2014.06.062

[105] Rico, A., Dimitrov, M.R., Van Wijngaarden, R.P.A., Satapornvanit, K., Smidt, H. and Van den Brink, P.J. (2014) Effects of the Antibiotic Enrofloxacin on the Ecology of Tropical Eutrophic Freshwater Microcosms. Aquatic Toxicology, 147, 92-104. http://dx.doi.org/10.1016/j.aquatox.2013.12.008

[106] Carlsson, G., Patring, J., Kreuger, J., Norrgren, L. and Oskarsson, A. (2013) Toxicity of 15 Veterinary Pharmaceuticals in Zebrafish (Danio rerio) Embryos. Aquatic Toxicology, 126, 30-41. http://dx.doi.org/10.1016/j.aquatox.2012.10.008

[107] Beri, S., Sidhu, P.K., Kaur, G., Chandra, M. and Rampal, S. (2014) Comparative Mutant Prevention Concentration and Antibacterial Activity of Fluoroquinolones against Escherichia coli in Diarrheic Buffalo Calves. Journal of Chemotherapy, 27, 312-316.

[108] Gebru Awji, E., Tassew, D.D., Lee, J.-S., Lee, S.-J., Choi, M.-J., Reza, M.A., et al. (2012) Comparative Mutant Prevention Concentration and Mechanism of Resistance to Veterinary Fluoroquinolones in Staphylococcus Pseudintermedius. Veterinary Dermatology, 23, 376-e69. http://dx.doi.org/10.1111/j.1365-3164.2012.01038.x

[109] Berghaus, L.J., Giguère, S. and Guldbech, K. (2013) Mutant Prevention Concentration and Mutant Selection Window for 10 Antimicrobial Agents against Rhodococcus equi. Veterinary Microbiology, 166, 670-675. http://dx.doi.org/10.1016/j.vetmic.2013.07.006

[110] Blondeau, J.M., Borsos, S., Blondeau, L.D., Blondeau, B.J.J. and Hesje, C.E. (2012) Comparative Minimum Inhibitory and Mutant Prevention Drug Concentrations of Enrofloxacin, Ceftiofur, Florfenicol, Tilmicosin and Tulathromycin against Bovine Clinical Isolates of Mannheimia haemolytica. Veterinary Microbiology, 160, 85-90. http://dx.doi.org/10.1016/j.vetmic.2012.05.006

[111] García Ovando, H., Gorla, N., Luders, C., Poloni, G., Errecalde, C., Prieto, G., et al. (1999) Comparative Pharmacokinetics of Enrofloxacin and Ciprofloxacin in Chickens. Journal of Veterinary Pharmacology and Therapeutics, 22, 209212. http://dx.doi.org/10.1046/j.1365-2885.1999.00211.x

[112] Anadón, A., Martínez-Larrañaga, M.R., Díaz, M.J., Fernández-Cruz, M.L., Martínez, M.A., Frejo, M.T., et al. (1999) Pharmacokinetic Variables and Tissue Residues of Enrofloxacin and Ciprofloxacin in Healthy Pigs. American Journal of Veterinary Research, 60, 1377-1382.

[113] Bidgood, T.L. and Papich, M.G. (2005) Plasma and Interstitial Fluid Pharmacokinetics of Enrofloxacin, Its Metabolite Ciprofloxacin, and Marbofloxacin after Oral Administration and a Constant Rate Intravenous Infusion in Dogs. nal of Veterinary Pharmacology and Therapeutics, 28, 329-341. http://dx.doi.org/10.1111/j.1365-2885.2005.00664.x

[114] Bugyei, K., Black, W.D. and McEwen, S. (1999) Pharmacokinetics of Enrofloxacin Given by the Oral, Intravenous and Intramuscular Routes in Broiler Chickens. Canadian Journal of Veterinary Research, 63, 193-200.

[115] Messenger, K.M., Papich, M.G. and Blikslager, A.T. (2012) Distribution of Enrofloxacin and Its Active Metabolite, Using an in Vivo Ultrafiltration Sampling Technique after the Injection of Enrofloxacin to Pigs. Journal of Veterinary Pharmacology and Therapeutics, 35, 452-459. http://dx.doi.org/10.1111/j.1365-2885.2011.01338.x

[116] Garcia Ovando, H., Gorla, N., Poloni, G., Trotti, N., Prieto, G. and Errecalde, C. (2000) Intravenous Pharmacokinetics of Ciprofloxacin in Goats. International Journal of Antimicrobial Agents, 15, 77-79. http://dx.doi.org/10.1016/S0924-8579(99)00146-6

[117] Tang, J., Yang, X., Zheng, Z., Yu, W., Hu, K. and Yu, H. (2006) Pharmacokinetics and the Active Metabolite of Enrofloxacin in Chinese Mitten-Handed Crab (Eriocheir sinensis). Aquaculture, 260, 69-76. http://dx.doi.org/10.1016/j.aquaculture.2006.05.036

[118] Suojala, L., Simojoki, H., Mustonen, K., Kaartinen, L. and Pyörälä, S. (2010) Efficacy of Enrofloxacin in the Treatment of Naturally Occurring Acute Clinical Escherichia coli Mastitis. Journal of Dairy Science, 93, 1960-1969. http://dx.doi.org/10.3168/jds.2009-2462

[119] Atif, F.A., Khan, M.S., Khan, M.A., Ashraf, M. and Avais, M. (2012) Chemotherapeutic Efficacy of Oxytetracycline, Enrofloxacin and Imidocarb for the Elimination of Persistent Anaplasma marginale Infection in Naturally Infected Sahiwal Cattle. Pakistan Journal of Zoology, 44, 449-456. 
[120] Facury-Filho, E.J., de Carvalho, A.Ú., Ferreira, P.M., Moura, M.F., Apolinário, B.C., Santos, L. de P.H., et al. (2012) Effectiveness of Enrofloxacin for the Treatment of Experimentally-Induced Bovine Anaplasmosis. Revista Brasileira de Parasitologia Veterinária, 21, 32-36. http://dx.doi.org/10.1590/S1984-29612012000100007

[121] Thompson, P.N., Van Amstel, S.R. and Henton, M. (1998) The Clinical Efficacy of Enrofloxacin in the Treatment of Experimental Bovine Pneumonic Pasteurellosis. Onderstepoort Journal of Veterinary Research, 65, 105-112.

[122] Robb, E.J., Tucker, C.M., Corley, L., Bryson, W.L., Rogers, K.C., Sturgess, K., et al. (2007) Efficacy of Tulathromycin versus Enrofloxacin for Initial Treatment of Naturally Occurring Bovine Respiratory Disease in Feeder Calves. Veterinary Therapeutics, 8, 127-135.

[123] Rawiwet, V., Chansiripornchai, P. and Chansiripornchai, N. (2010) Comparison of the Efficacy of Enrofloxacin against Escherichia coli or Pasteurella multocida Infection in Chickens. The Thai Journal of Veterinary Medicine, 40, 297-301.

[124] Barbour, E.K., Hamadeh, S., Talhouk, R., Sakr, W. and Darwish, R. (1998) Evaluation of an Enrofloxacin-Treatment Program against Mycoplasma gallisepticum Infection in Broilers. Preventive Veterinary Medicine, 35, 91-99. http://dx.doi.org/10.1016/S0167-5877(98)00055-5

[125] Randall, L.P., Cooles, S.W., Coldham, N.C., Stapleton, K.S., Piddock, L.J.V. and Woodward, M.J. (2006) Modification of Enrofloxacin Treatment Regimens for Poultry Experimentally Infected with Salmonella enterica Serovar Typhimurium DT104 To Minimize Selection of Resistance. Antimicrobial Agents and Chemotherapy, 50, 4030-4037. http://dx.doi.org/10.1128/AAC.00525-06

[126] Huff, W.E., Huff, G.R., Rath, N.C., Balog, J.M. and Donoghue, A.M. (2004) Therapeutic Efficacy of Bacteriophage and Baytril (Enrofloxacin) Individually and in Combination to Treat Colibacillosis in Broilers. Poultry Science, 83, 1944-1947. http://dx.doi.org/10.1093/ps/83.12.1944

[127] Garmyn, A., Martel, A., Froyman, R., Nauwynck, H., Duchateau, L., Haesebrouck, F., et al. (2009) Efficacy of Four Enrofloxacin Treatment Regimens against Experimental Infection in Turkey Poults with Avian Pneumovirus and Ornithobacterium rhinotracheale. Avian Pathology, 38, 287-292. http://dx.doi.org/10.1080/03079450903055413

[128] Neer, T.M., Eddlestone, S.M., Gaunt, S.D. and Corstvet, R.E. (1999) Efficacy of Enrofloxacin for the Treatment of Experimentally Induced Ehrlichia Canis Infection. Journal of Veterinary Internal Medicine, 13, 501-504. http://dx.doi.org/10.1111/j.1939-1676.1999.tb01470.x

[129] Reddy, S., Kumari, K.N., Rao, V.V., Rayulu, V.C. and Sivajothi, S. (2014) Efficacy of Enrofloxacin in the Treatment of Recurrent Pyoderma in Dogs. Journal of Advanced Veterinary and Animal Research, 4, 108-112.

[130] Wanke, M.M., Delpino, M.V. and Baldi, P.C. (2006) Use of Enrofloxacin in the Treatment of Canine Brucellosis in a Dog Kennel (Clinical Trial). Theriogenology, 66, 1573-1578. http://dx.doi.org/10.1016/j.theriogenology.2006.01.034

[131] Kordick, D.L., Papich, M.G. and Breitschwerdt, E.B. (1997) Efficacy of Enrofloxacin or Doxycycline for Treatment of Bartonella henselae or Bartonella clarridgeiae Infection in Cats. Antimicrobial Agents and Chemotherapy, 41, 24482455.

[132] Gerhardt, N., Schulz, B.S., Werckenthin, C. and Hartmann, K. (2006) Pharmacokinetics of Enrofloxacin and Its Efficacy in Comparison with Doxycycline in the Treatment of Chlamydophila felis Infection in Cats with Conjunctivitis. Veterinary Record, 159, 591-594. http://dx.doi.org/10.1136/vr.159.18.591

[133] Slate, A.R., Bandyopadhyay, S., Francis, K.P., Papich, M.G., Karolewski, B., Hod, E.A., et al. (2014) Efficacy of Enrofloxacin in a Mouse Model of Sepsis. Journal of the American Association for Laboratory Animal Science, 53, 381-386.

[134] Barbosa, B.F., Gomes, A.O., Ferro, E.A.V., Napolitano, D.R., Mineo, J.R. and Silva, N.M. (2012) Enrofloxacin Is Able to Control Toxoplasma gondii Infection in Both in Vitro and in Vivo Experimental Models. Veterinary Parasitology, 187, 44-52. http://dx.doi.org/10.1016/j.vetpar.2011.12.039

[135] Mahler, M., Stunkel, S., Ziegowski, C. and Kunstyr, I. (1995) Inefficacy of Enrofloxacin in the Elimination of Pasteurella multocida in Rabbits. Laboratory Animals, 29, 192-199. http://dx.doi.org/10.1258/002367795780740195

[136] Roque, A. and Gomez-Gil, B. (2003) Therapeutic Effects of Enrofloxacin in an Experimental Infection with a Luminescent Vibrio harveyi in Artemia franciscana Kellog 1906. Aquaculture, 220, 37-42. http://dx.doi.org/10.1016/S0044-8486(02)00272-7 


\section{Abbreviations}

ADI: Acceptable Daily Intakes;

EMA: European Medicines Agency;

Gyrase: DNA Topoisomerase II;

G-DNA: Clived DNA Sequence;

HLC: Henry’s Law Constant;

HPLC: High Performance Liquid Chromatography;

MAR: Multiple Antimicrobial Resistance;

MIC: Minimum Inhibitory Concentration;

MPC: Mutant Prevention Concentration;

MRL: Maximum Residue Limits;

PCR: Polymerase Chain Reaction;

NOEL: No Observed Effect Level;

PMQR: Plasmide-Mediated Quinolone Resistance;

QRDR: Quinolone Resistance-Determining Region;

SPC: Summary of Product Characteristics;

Topo IV: DNA Topoisomerase IV;

T-DNA: Transported DNA Sequence. 